\title{
New Records of Culicidae Species with Medical Importance in the State of Paraíba, Brazil
}

\author{
Andressa de Oliveira Aragão ${ }^{1}$, Hamilton Antônio de Oliveira Monteiro ${ }^{2}$ and Eduardo Barbosa Beserra ${ }^{1}$ \\ 1. Laboratory of Entomology, Center for Integrated Pest Management, Department of Biology, State University of Paraíba, Campina \\ Grande 58109-753, PB, Brazil \\ 2. Section of Arbovirology and Hemorrhagic Fever, Laboratory of Entomology, Evandro Chagas Institute, Ananindeua 67030-000, \\ PA, Brazil
}

\begin{abstract}
This paper aimed to investigate the Culicidae fauna in the state of Paraíba and review the possible pathogens vector capacity of captured specimens. The catches occurred on November from day 17 to 21, 2014 in Mata do Buraquinho, João Pessoa/PB and were performed with the use of aerial insect net and an oral aspirator. There were 88 Culicidae specimens collected from the Buraquinho Forest. This is the first report of Aedes fulvithorax, A. scapularis, A. serratus, A. taeniorhynchus, Anopheles nimbus, Coquillettidia albicosta, C. venezuelensis, Limatus durhamii and Mansonia titillans, also genus Wyeomyia in Paraíba state. The capacity of these mosquitoes to transmit diseases, mainly arboviruses, outlines the need for epidemiological surveillance in the state.
\end{abstract}

Key words: Culicidae fauna, biodiversity, epidemiology.

\section{Introduction}

Culicidae belongs to the order Diptera, suborder Nematocera and comprises about 3,600 species [1]. It is popularly known as mosquitoes, gnats, awls, sovelas, mossorongos, carapanãs and pernilongos. They are delicate insects that vary from $3 \mathrm{~mm}$ to 9 $\mathrm{mm}$ in length [2]. They constitute a family of strong epidemiological importance due to females with hematophagy habits facilitating the transmission of viruses, protozoa and helminths to vertebrates, including man [3]. Studies on diversity and distribution of these insects enable the description of new species, or simply the description of species in not previously mentioned environments, as is the case of this study, besides contributing to the understanding of epidemiological scenarios when looking at vectors range and habitat $[4,5]$.

Forest ecosystems have strongly suffered from the anthropogenic activities that cause the fragmentation of these environments [6]. As a consequence, the

Corresponding author: Andressa de Oliveira Aragão, B.Sc., research field: medical entomology. disturbance of all the fauna, especially with the Culicidae fauna, is observed. They suffer with the decrease of ideal conditions for survival, as well as with the greater proximity with the man, and can accidentally transmit several pathogens. The understanding of the maintenance of these insects in these areas has also been important, since it has been confirmed that fragments of Atlantic Forest are favorable to the survival and reproduction of mosquitoes, leaving the breach for possible new identifications in these areas [7].

In the Northeast Brazil, little was done about the description of the fauna of Culicidae in conservation areas, mainly in areas of Atlantic Forest, since most of these studies are concentrated in the states of Goiás, Pará, São Paulo, Rio de Janeiro, Santa Catarina and Paraná. The Northeastern Brazilian states that best fitted the scenarios studied is Maranhão. For example, Paterno and Marcondes [8] carried out a survey of the Culicidae fauna in an area of Atlantic Forest in the city of Florianópolis, SC, where 358 specimens belonging to 22 species were collected and among 
them 14 were reported for the first time in the state, with emphasis on the genus Wyeomyia.

The epidemiological scenario in which mosquitoes are involved determines their impact on the country's health and economy. With the increase of urbanization, the contact of the vector with the man has been intensified. With the frequent modification of the habitat, several species of mosquitoes tend to undergo new adaptations and influences of proliferative character, consequently modifying the epidemiological pictures of the infections transmitted by these vectors [9]. In this way, basal studies of faunal survey of Culicidae in fragments of anthropic forests and surrounding by urbanized areas, such as Buraquinho Forest in João Pessoa, Paraíba, can facilitate the identification and subsequent control of these mosquitoes, besides contributing in future to understanding of implication in the epidemiological scenario of this city [10-13]. So, the aim of this research was to conduct a preliminary survey of the Culicidae fauna in fragments of the Buraquinho Forest from November 17 to 21, 2014 to describe the occurrence of species with medical importance.

\section{Materials and Methods}

The first Culicidae fauna survey in the state of Paraíba was performed from November 17 to 21, 2014 at Mata do Buraquinho $\left(7^{\circ} 08^{\prime} 28.98^{\prime \prime} \mathrm{S}\right.$ and $34^{\circ} 51^{\prime}$ 34.92 " W), the state's largest remnant of the Atlantic Forest [14], with 515 ha, located in an urban area of the city of João Pessoa.

Samples were collected in 12 points of a $450 \mathrm{~m}^{2}$ transect in the morning period from 9:30 am, with a period of $10 \mathrm{~min}$ at each point, totaling $2 \mathrm{~h}$. Capture of adult mosquitoes was carried out with the aid of an aerial insect net and an oral aspirator. At the end of the collection at each point, the tube was placed into an ice styrofoam for dormancy and death of the mosquitoes. Then, they were packed in identified jars containing cotton and naphthalene.

The tubes containing adult specimens were carefully packed inside a cardboard box with bubble wrap and styrofoam to avoid damage and sent to the Evandro Chagas Institute, Ananindeua/PA for taxonomic identification by experienced entomologists. Morphological keys (dichotomous keys) were used only when necessary [15].

\section{Results and Discussion}

\subsection{Specimens Captured from Buraquinho Forest}

There were 88 Culicidae specimens collected from the Buraquinho Forest between November 17 and 21, 2014 (Table 1). Although the catches were carried out during the day, it is worth noting that not all captured mosquitoes have daytime hematophagy habits, some are crepuscular, like anophelines.

In this study, some species were recorded for the first time to the state, such as Aedes fulvithorax (Lutz, 1904), Aedes scapularis (Rondani, 1848), Aedes serratus (Theobald, 1901), Aedes taeniorhynchus (Wiedemann, 1821), Anopheles nimbus (Theobald, 1902), Coquillettidia albicosta (Peryassú, 1908), Coquillettidia venezuelensis (Theobald, 1912), Limatus

Table 1 Species and respective specimens number of Culicidae captured in Mata do Buraquinho, João Pessoa/PB between November 17 and 21, 2014.

\begin{tabular}{ll}
\hline Species & Specimens number \\
\hline Aedes fulvithorax & 1 \\
Aedes scapularis & 4 \\
Aedes serratus & 2 \\
Aedes taeniorhynchus & 6 \\
Anopheles nimbus & 1 \\
Anopheles sp. & 1 \\
Coquillettidia albicosta & 4 \\
Coquillettidia sp. & 1 \\
Coquillettidia venezuelensis & 1 \\
Culex sp. & 6 \\
Culex sp. & 1 \\
Limatus durhamii & 3 \\
Limatus sp. & 3 \\
Mansonia sp. & 2 \\
Mansonia titillans & 13 \\
Wyeomyia sp. & 39 \\
\hline Total & 88 \\
\hline
\end{tabular}


durhamii (Theobald, 1901) and Mansonia titillans (Walker, 1848), besides the Wyeomyia (Theobald, 1901). It should be noted that although Aedes taeniorhynchus was not previously registered in Paraíba, its presence has been already reported in virtually all Brazilian coast [16].

\subsection{The Possible Pathogens Vector Capacity of Captured Specimens}

Of the mentioned species, the pathogens vector capacity of most of them is known, such as Aedes scapularis as a possible reservoir of bancroftian filariasis in the Neotropics region [17], as well as being possibly involved in the transmission of the Rocio virus (ROCV) in the Vale do Ribeira, SP between the years of 1975 and 1978 [18]. Evidence indicates this species is capable of transmitting yellow fever (YFV) [19], and has already been found infected with Saint Louis encephalitis agent (SLEV) [20]. In Belém/Pará and Trinidad, several viruses were isolated from this species when collected in the nature, like the Ilhéus (ILHV), Cache Valley, Kairi, Wyeomyia and Melao viruses [21-25]. The Venezuelan equine encephalitis virus (VEEV) which is able to infect humans [26] is also included, as well as the Caraparu virus [23, 27].

Aedes serratus has been considered a possible secondary vector of YFV in Southern Brazil [28], besides being a possible VEEV vector in Ecuador [29]. Infection with ILHV was found in Trinidad, Mayaro (MAYV) in Colombia, Aura and Una in Belém/PA $[21,30,31]$. This incriminates it as a great medical importance species.

Aedes taeniorhynchus species has also shown importance in the public health setting, since under laboratory conditions, it was observed as a good eastern equine encephalitis virus (EEEV) carrier. Aedes terniorhynchus has ability to become infected with VEEV [32].

Anopheles nimbus also has capacity for transmission of VEEV, of which it was possible to isolate serotypes III and IV [33, 34]. It is known that Anopheles nimbus behaves as a synanthropic and anthropophilic species [35], which may facilitate a possible virus transmission to domestic animals or even to human populations.

Coquillettidia albicosta species has been observed with ability to become infected by Tonate virus in Cayenne, French Guiana, in 1973 [36]. While Coquilletidia venezuelensis has been found infected by Bussuquara, Catu, Guama, Itaporanga, Moju, Mucambo (MUCV) and Oriboca viruses [37] and Dengue virus in Cayenne, French Guiana, in 1977 [36].

Mansonia titillans species has epidemiologic importance, as it has been already reported as vector of VEEV [38]. A peculiar aggressiveness behavior is observed on it, and it may even pierce the abdomen of other mosquitoes, sucking blood and other fluids in the intestine [39]. Such behavior may favor this mosquito to contract etiologic agents that may be present in the liquid collected from the abdomen of other species. In addition, it is a mosquito that is often found infected with Dermatobia hominis (Linnaeus Jr., 1781), leaving open the possibility that it is responsible for myiasis dissemination for both man and domestic animals [17].

The other species do not have their significance epidemiology clarified, like Aedes fulvithorax, which is not frequent in Culicidae fauna studies and not found naturally infected with arboviruses [37]. About Limatus durhamii, its ability to be infected by the Guamá virus [37] is known, and the predatory behavior of its larvae against other Culicidae larvae stands out [40].

Wyeomyia genus took its epidemiological significance when it was possible to isolate from Wyeomyia melanocephala (Dyar \& Knab, 1906) a viral agent called Wyeomyia virus [41], in addition to Kairi virus and others that have been isolated from a number of different species of this genus [22]. It is assumed that these mosquitoes play an important role 
in spreading Wyeomyia and Kairi, in addition to other viruses in natural environment $[17,27]$.

The scarcity of studies on Culicidae in Paraíba is one of the factors contributing to the lack of records of its species in the state. Many studies in the state are concentrated in the Aedes aegypti (Linnaeus, 1762) and Aedes albopictus (Skuse, 1894) species, dealing mainly with biological and bio-ecological studies on insecticide resistance [42-45], population [46] and competition genetics [47, 48]. These both species were not founded during the catchings.

Natural fragments inserted in urban areas have favorable conditions to cause adaptive changes in insects and in its relations with the human population [49], enabling mosquitoes hosting and facilitating pathogens transmission. In the period from March 2008 to September 2010, the presence of antibodies in robust capuchin monkeys (Cebus libidinosus Spix, 1823) to MAYV, SLEV, EEEV, western equine encephalitis (WEEV), MUCV, YFV, ILHV, ROCV and Oropouche (OROV) viruses was observed in different titrations in the state of Paraíba [50]. This seroepidemiological survey confirms the need for epidemiological surveillance, given that such viruses can be carried by the species that are being described to the state.

Culicidae present in Mata do Buraquinho may be subject to adaptation and narrow their relation with the urban environment, subsequently causing several diseases for the population located in the vicinity of the forest. Thus, there is a need for more studies on Culicidae diversity in Paraíba in order to turn the attention of health and environmental agencies to the possibility of new records of diseases that may eventually occur in the state.

\section{Conclusions}

The clarified epidemiological importance of the species present here strengthens the need for surveillance of this remnant of Atlantic Forest that is located in the midst of a metropolis, in which it has already been possible to isolate arbovirus monkeys that can be transmitted by these vectors. In-depth surveys of mosquito fauna, their ecology should be considered in order to prevent arbovirus outbreaks.

\section{Acknowledgments}

Thanks to the State University of Paraíba for the opportunity for developing research, Evandro Chagas Institute/PA for the collaboration in the identification, the Botanical Garden Benjamin Maranhão/PB by opening the space for the study and Shirley Lima and Berlandio Jackson Farias by contribution in catches of specimens.

\section{References}

[1] Crosskey, R. W. 1988. "Old Tools and New Taxonomic Problems in Bloodsucking Insects." In Biosystematics of Haematophagous Insects, edited by Service, M. W. Oxford: Clarendon Press, 1-18.

[2] Rafael, J. A., Melo, G., Carvalho, C., Casari, S., and Constantino, R. 2012. Insects of Brazil: Diversity and Taxonomy. Ribeirão Preto: Holos. (in Portuguese)

[3] Eiras, A. E. 2005. "Culicidae.” In Human Parasitology, 11th ed., edited by Neves, D., Melo, A., Linardi, P. M., and Vitor, R. São Paulo: Atheneu, 355-67. (in Portuguese)

[4] Forattini, O. P. 1962. Medical Entomology. Vol. 1. São Paulo: Department of Parasitology, University of São Paulo, 664. (in Portuguese)

[5] Hutchings, R. S., Sallum, M. A., Ferreira, R. L., and Hutchings, R. W. 2005. "Mosquitoes of the Jaú Park and Their Potential Importance in Brazilian Amazonia." Med. Vet. Entomol. 19 (4): 428-41.

[6] Viana, V. M., and Pinheiro, L. A. 1998. "Conservation of Biodiversity in Forest Fragments." Technical Series IPEF 12 (32): 25-42. (in Portuguese)

[7] Guedes, M. L. 2010. "Fauna of Culicidae (Diptera) in Remnant of the Atlantic Forest Biome, Antonina/PR." Master dissertation, Sector of Biological Sciences, Federal University of Paraná, Curitiba. (in Portuguese)

[8] Paterno, U., and Marcondes, C. 2004. "Anthropophilic Mosquitoes of Morning Activity in Atlantic Forest, Florianópolis, SC.” Rev. Saúde Pública 38 (1): 133-5. (in Portuguese)

[9] Forattini, O. P. 1998. "Culicidae Mosquitoes as Emerging Vectors of Infections.” Rev. Saúde Pública 32 (6): 497-502. (in Portuguese)

[10] Dorvillé, L. F. 1996. "Mosquitoes as Bioindicators of 
Forest Degradation in Southeastern Brazil, a Statistical Evaluation of Published Data in the Literature." Studies on Neotropical Fauna and Environment 31 (2): 68-78.

[11] Forattini, O. P., and Massad, E. 1998. "Culicidae Vectors and Anthropic Changes in a Southern Brazil Natural Ecosystem." Ecosystem Health 4 (1): 9-19.

[12] Montes, J. 2005. "Fauna of Culicidae from Serra da Cantareira, São Paulo, Brazil.” Rev. Saúde Publica 39 (4): 578-84. (in Portuguese)

[13] Zequi, J. A., and Lopes, J. 2001. "Culicideofauna (Diptera) Found in the Internodes of the Bamboo in a Residual Forest in the Urban Area of Londrina, Paraná, Brazil.” Rev. Bras. Zool. 18 (2): 429-38. (in Portuguese)

[14] Gadelha Neto, P., Barbosa, M. R., and Thomas, W. W. 2012. "Vegetation and Flora of the Buraquinho Forest/Botanical Garden, João Pessoa, Paraíba, Brazil." In Proceedings of the 63rd National Congress of Botany "Botany in the Face of Global Changes", 337. (in Portuguese)

[15] Forattini, O. P. 2002. Medical Culicidology. Vol. 2. São Paulo: EDUSP. (in Portuguese)

[16] Agramonte, N. M. 2014. "Featured Creatures." EENY-591, University of Florida. Accessed January 31, 2015. http://entnemdept.ufl.edu/Creatures/AQUATIC/ aedes_taeniorhynchus.htm.

[17] Forattini, O. P. 1965. Medical Entomology. Vol. 2. São Paulo: Department of Parasitology, University of São Paulo, 507. (in Portuguese)

[18] Mitchael, C. J., and Forattini, O. P. 1984. "Experimental Transmission of Rocio Encephalitis Virus by Aedes scapularis (Diptera: Culicidae) from the Epidemic Zone in Brazil." J. Med. Entomol. 21 (1): 34-6.

[19] Soper, F. L., Penna, H. A., Cardoso, E., Serafim Jr., J., Frobisher Jr., M., and Pinheiro, J. 1933. "Yellow Fever without Aedes aegypti: Study of Rural Epidemic in Valle do Chanaan, Espirito Santo, Brazil, 1932." Am. J. Epidemiol. 18 (3): 555-87.

[20] Aitken, T. H., Downs, W. G., Spence, L., and Jonkers, A. H. 1964. "St. Louis Encephalitis Virus Isolations in Trinidad, West Indies, 1953-1962." Am. J. Trop. Med. Hyg. 13: 450-1.

[21] Aitken, T. H. 1960. "A Survey of Trinidadian Arthropods for Natural Virus Infections (August, 1953 to December, 1958)." Mosquito News 20: 1-10.

[22] Anderson, C. R., Aitken, T. H., Spence, L. P., and Downs, W. G. 1960. "Kairi Virus, a New Virus from Trinidad Forest Mosquitoes.” Am. J. Trop. Med. Hyg. 9: 70-2.

[23] Causey, O. R., Causey, C. E., Maroja, O. M., and Macedo, D. G. 1961. "The Isolation of Arthropod-Borne Viruses, Including Members of Two Hitherto Undescribed Serological Groups, in the Amazon Region of Brazil." Am. J. Trop. Med. Hyg. 10: 227-49.
[24] Downs, W. G., Spence, L., Aitken, T. H., and Whitman, L. 1961. "Cache Valley Virus Isolated from a Trinidadian Mosquito, Aedes scapularis." West Indian Medical Journal 10: 13-5.

[25] Spence, L., Anderson, C. R., Aitken, T. H., and Downs, W. G. 1962. "Melao Virus, a New Agent Isolated from Trinidadian Mosquitoes." Am. J. Trop. Med. Hyg. 11: 687-90.

[26] Beer, J. 1999. Infectious Diseases of Domestic Animals. São Paulo: Roca, 380. (in Portuguese)

[27] Forattini, O. P. 1965. Medical Entomology. Vol. 3. São Paulo: Department of Parasitology, University of São Paulo, 416. (in Portuguese)

[28] Cardoso, J. C., De Almeida, M. A., Dos Santos, E., Da Fonseca, D. F., Sallum, M. A., Noll, C. A., Monteiro, H. A., Cruz, A. C., Carvalho, V. L., Pinto, E. V., Castro, F., Nunes Neto, J., Segura, M. N., and Vasconcelos, P. F. 2010. "Yellow Fever Virus in Haemagogus leucocelaenus and Aedes serratus Mosquitoes, Southern Brazil, 2008." Emerging Infectious Disease Journal 16 (12): 1918-24.

[29] Levi-Castillo, R. 1952. "The Problem of Human and Equine Encephalomyelitis in Ecuador." Acta Tropica 9 (1): 77-80.

[30] Groot, H., Morales, A., and Vidales, H. 1961. "Virus Isolations from Forest Mosquitoes in San Vicente de Chucuri, Colombia." Am. J. Trop. Med. Hyg. 10 (3): 397-402.

[31] Causey, O. R., Casals, J., Shope, R. E., and Udomsakdi, S. 1963. "Aura and Una, Two New Group A Arthropod-Borne Viruses.” Am. J. Trop. Med. Hyg. 12: $777-81$.

[32] Smith, D. R., Adams, A. P., Kenney, J. L., Wang, E., and Weaver, S. C. 2008. "Venezuelan Equine Encephalitis Virus in the Mosquito Vector Aedes taeniorhynchus: Infection Initiated by a Small Number of Susceptible Epithelial Cells and a Population Bottleneck." Virology 372 (1): 176-86.

[33] Vasconcelos, P. F., Travassos Da Rosa, J. F., Travassos Da Rosa, A. P., Degallier, N., Pinheiro, F. P., and Sá Filho, G. C. 1991. "Epidemiology of Arbovirus Encephalitis in the Brazilian Amazon." Revista do Instituto de Medicina Tropical de São Paulo 33 (6): 465-76. (in Portuguese)

[34] Travassos Da Rosa, A. P., Travassos Da Rosa, J. F., Pinheiro, F. P., and Vasconcelos, P. F. 1996. Infectious and Parasitic Diseases: Amazonian Approach. Belém: CEJUP. (in Portuguese)

[35] Camargo, M. F., Silva, I. G., and Isac, E. 1993. "Occurrence of Anopheles (Stegomyia) nimbus (Theobald, 1903) (Diptera: Culicidae) in the Home Environment, in the Urban Area of Goiânia, Goiás, Brazil.” Revista 
Pesquisa Agropecuária Tropical 22 (1): 101. (in Portuguese)

[36] Robin, Y., Lhuillier, M., Girault, G., Pajot, F. X., and Dégallier, N. 1982. "Dengue Viruses and Other Arboviruses in French Guiana." In Proceedings of International Symposium on Tropical Arboviruses and Haemorrhagic Fevers, 391-6.

[37] Segura, M. N., and Castro, F. 2007. Atlas of Culicidae in the Brazilian Amazon: Characteristics of Hematophagous Insects of the Family Culicidae. Belém: Instituto Evandro Chagas, 78. (in Portuguese)

[38] Mendéz, W., Liria, J., Navarro, J. C., Garcia, C. Z., Freier, J. E., Salas, R., Weaver, S. C., and Barrera, R. 2001. "Spatial Dispersion of Adult Mosquitoes (Diptera: Culicidae) in a Sylvatic Focus of Venezuelan Equine Encephalitis Virus." J. Med. Entomol. 38 (6): 813-9.

[39] Burton, G. J. 1963. "Feeding of Mansonia titillans (Walker) on Other Mosquitoes." Mosquito News 23 (2): 164.

[40] Lopes, J. 1997. "Ecology of Mosquitoes (Diptera: Culicidae) in Natural and Artificial Breeding Sites of Rural Area in Northern Paraná State, Brazil.” Revista de Saúde Pública 31 (4): 370-7. (in Portuguese)

[41] Roca-Garcia, M. 1944. "The Isolation of Three Neurotropic Viruses from Forest Mosquitoes in Eastern Colombia." Journal of Infectious Diseases 75 (2): 160-9.

[42] Beserra, E., Santos, J. W., Santos, T. S., Fernandes, C. R. M., and Castro Jr., F. P. 2006. "Biology and Thermal Requirements of Aedes aegypti L. (Diptera: Culicidae) from Four Bioclimatic Regions of Paraíba." Neotrop. Entomol. 35 (6): 853-60.

[43] Beserra, E., Fernandes, C. R., Queiroga, M. F., and Castro Jr., F. P. 2007. "Resistance of Populations of Aedes aegypti L. (Diptera: Culicidae) to the Organophosphate Temephos in Paraíba." Neotrop, Entomol. 36 (2): 303-7.
[44] Beserra, E., Aguiar, D. L., Leandro, R., Henriques, A. D., and Diniz, M. M. 2014. "Resistance of Aedes aegypti to Temephos and Adaptive Disadvantages." Revista de Saúde Pública 48 (5): 775-82. (in Portuguese)

[45] Diniz, D. F. 2014. "Biological Cost Associated with Resistance to Insecticide Temephos in Aedes aegypti Populations (Diptera: Culicidae)." Accessed February 27, 2014. https://www.arca.fiocruz.br/handle/icict/12166. (in Portuguese)

[46] Gambarra, W. P., Martins, W. F., Lucena-Filho, M. L., Albuquerque, I. M., Apolinário, O. K., and Beserra, E. 2013. "Spatial Distribution and Esterase Activity in Populations of Aedes (Stegomyia) aegypti (Linnaeus) (Diptera: Culicidae) Resistant to Temephos." Rev. Soc. Bras. Med. Trop. 46 (2): 176-84. (in Portuguese)

[47] Leandro, R., Beserra, E., Marinho, R. A., Pereira, B. N., Gambarra, W. P., and Sousa, D. L. 2012. "Competition and Comparative Biology of Aedes aegypti (L.) and Aedes albopictus (S.)." In Proceedings of the XXIV Brazilian Congress of Entomology. (in Portuguese)

[48] Leandro, R., Beserra, E., Candido, L. P., Lopez, L. C., Cardoso, H. C., and Silva, B. Q. 2012. "Distribution Patterns of Aedes aegypti and Aedes albopictus in the Municipality of João Pessoa, PB.” In Proceedings of the XXIV Brazilian Congress of Entomology. (in Portuguese)

[49] Taipe-Lagos, C. B., and Natal, D. 2003. "Abundance of Culicidae in a Preserved Metropolitan Area and Its Epidemiological Implications.” Revista de Saúde Pública 37 (3): 275-9. (in Portuguese)

[50] Laroque, P. O., Valença-Montenegro, M. M., Ferreira, D. R. A., Chiang, J. O., Cordeiro, M. T., Vasconcelos, P. F., and Silva, J. C. 2014. "Epidemiologic Survey for Arbovirus in Galician Capuchin Monkeys (Cebus flavius) Free Living in Paraíba and Captive Capuchin Monkey (Cebus libidinosus) from Northeast Brazil." Pesq. Vet. Bras. 34 (5): 462-8. (in Portuguese) 